\title{
Pemberian Hak Remisi Bagi Narapidana Narkotika Berstatus Justice Collaborator
}

\author{
Jupri \\ Fakultas Hukum Universitas Ichsan Gorontalo, Indonesia \\ E-mail :jupri04hukum@gmail.com
}

\begin{abstract}
Indonesia as a paradise for narcotics distribution in Southeast Asia is inseparable from the influence of the Golden Triangle Syndicate, which is a narcotics distribution syndicate in accordance with the golden triangle line that covers three countries, Thailand, Laos and Myanmar. All in various narcotics cases revealed by the National Narcotics Agency or the Police as if the state was made helpless, some convicts who can be behind bars with Correctional Institutions (Lapas) are able to connect narcotics distribution in Indonesia. Therefore, it is necessary to uncover strategies through the role of Justice Collaborator but they are not easy to implement. This study discusses how to request remission rights for narcotics prisoners with Juctice Collaborator status in Lapas Class III Pohuwato. The research method used in this study is the normative-empirical legal research method. The results of the study show that remission is a right for inmates so that it cannot be eliminated, but it can be limited by the additional requirements that must be fulfilled, namely becoming a Justice Collaborator. From 28 narcotics prisoners, only 8 people get remission. As for prisoners who have not received remission, they are constrained in a letter of justice collaborator from investigators / prosecutors.
\end{abstract}

Keywords : Justice Collaborator: Narkotics, Remission

\begin{abstract}
Abstrak
Indonesia menjadi surga peredaran narkotika di Asia Tenggara tidak lepas dari pengaruh jaringan sindikat The Golden Triangle, sindikat pengedar narkotika dalam kawasan garis segitiga emas yang berasal dari tiga negara pengedar Thailand, Laos, dan Myanmar. Bahkan dalam berbagai kasus peredaran narkotika yang di ungkap oleh BNN atau Kepolisian seakan negara dibuat tidak berdaya, beberapa terpidana yang mendekam dibalik jeruji besi Lembaga Pemasyarakatan (Lapas) mampu mengendalikan peredaran narkotika di Indonesia. Olehnya itu strategi mengungkap kejahatan melalui Justice Collaborator perlu dimaksimalkan namun tidak mudah dalam implementasi. Penelitian ini bertujuan untuk mengetahui bagaimana pemberian hak remisi bagi narapidana narkotika berstatus
\end{abstract}


Juctice collaborator di Lapas Klas III Pohuwato. Metode penelitian yang digunakan dalam penelitian ini adalah metode penelitian hukum.normatif-empiris. Hasil penelitian menunjukkan remisi merupakan hak bagi narapidana sehingga tidak dapat dihilangkan, namun dapat dibatasi dengan adanya syarat tambahan yang harus terpenuhi yaitu menjadi Justice Collaborator. Dari 28 orang narapidana narkotika hanya 8 orang yang mendapatkan remisi. Sedangkan bagi narapidana yang belum mendapatkan remisi, terkendala di surat Justice Collaborator dari penyidik/kejaksaan.

Kata Kunci: Justice Collaborator; Narkotika; Remisi

\section{A. Latar Belakang Masalah}

Justice Collaborator seiring perkembangan hukum pidana menjadi istilah yang sangat familiar ditengah-tengah masyarakat kita. Di Indonesia sendiri, istilah Justice Collaborator dipersamakan dengan pemukul kentongan, saksi pelaku yang bekerjasama, ada pula yang mengistilahkannya sebagai saksi pelaku. Awalnya, Justice Collaborator digunakan oleh penegak hukum di Amerika Serikat untuk mengungkap kejahatan yang bersifat organized crime, yaitu suatu bentuk kejahatan dimana para pelakunya memiliki jaringan yang luas serta berkomplot yang disertai dengan peran masing-masing untuk melakukan kejahatan secara terorganisir dan rapi, demi tujuan utama memperoleh uang maupun kekuasaan, baik dengan cara melawan hukum maupun dengan jalan menghindari hukum ${ }^{1}$.

Sebagai contoh dari organized crime ini, misalnya di benua Asia, siapa yang tidak mengenal Yakuza (Jepang) dan begitupun di Benua Amerika, siapa yang tidak mengenal Al Capone (Amerika). Yakuza sendiri merupakan nama dari sindikat terorganisir dan telah ada pada jaman ke-Shogunan Jepang. Sedangkan Al-Capone (Alphonse Gabriel Capone), merupakan pimpinan gengster di Chicago dan menjelma menjadi mafia legendaris Amerika Serikat. Organisasi ini bukan hanya bergerak di bidang kriminalitas, tetapi telah masuk ke dunia politik dan pejabat tinggi. Sebagai komplotan kriminal, baik keluarga mafia di Amerika

\footnotetext{
${ }^{1}$ Dalam perkembangannya, pelakunya tidak hanya bergerak dibidang kriminalitas, namun menyusup masuk dalam bidang politik dan pemerintahan dan menjadi pejabat tinggi sedangkan uang hasil kejahatannya disembunyikan dengan berbagai cara demi menyamarkan dan atau mengaburkan asal-usul uang hasil kejahatannya.
} 
Serikat maupun Yakuza Jepang terdapat kesamaan yakni menganut prinsip sumpah Omerta ${ }^{2}$ demi menjaga rahasia organisasinya.

Selain Justice Collaborators, strategi lain yang dapat diterapkan dalam mengungkap kejahatan adalah Whistleblowers. Didalam Hukum Acara Pidana Indonesia, Justice Collaborators maupun Whistleblowers baru digunakan secara yuridis sejak keluarnya Surat Edaran Mahkamah Agung (SEMA) No. 04 Tahun 20113. Dari penjelasan/uraian yang terdapat dalam SEMA tersebut, Whistleblowers dapat dipersamakan dengan istilah "si peniup pluit" dan dimaknai sebagai tindakan berani yang dilakukan oleh seseorang yang pertama kali melaporkan kepada otoritas berwenang dalam mengungkap skandal kejahatan yang terjadi dilingkungan kerjanya, tentu dengan ketentuan bahwa pelapor ini bukan merupakan bagian dari pelaku kejahatan yang dilaporkannya. Sedangkan untuk Justice Collaborators dimaknai sebagai saksi pelaku yang berkerjasama dengan aparat penegak hukum dalam mengungkap kejahatan.

Perlu dipahami, jauh hari sebelum Justice Collaborators booming melalui pemberitaan media dan kemudian diatur dalam SEMA, aparat penegak hukum maupun masyarakat awalnya lebih familiar dengan istilah "saksi mahkota" atau crown $_{\text {witness }}{ }^{4}$ yaitu pemberian kompensasi berupa pengurangan ancaman hukuman bagi salah salah satu pelaku kejahatan yang ditarik sebagai saksi kunci untuk menjerat pelaku-pelaku lainnya.

Jika di Indonesia, Justice Collaborators familiar belakangan. Beda halnya di negera Eropa Kontinental, seperti Francis, Italia, dan Belanda yang telah sejak lama mengimplementasikan sistem ini dalam mengungkap kejahatan

${ }^{2}$ Omerta adalah sumpah para mafia untuk menyimpan rahasia (bisu) serta menuntut kesetian dan kepatuhan penuh bagi setiap anggota untuk tidak memberikan informasi bagi seseorang yang bukan anggota organisasinya, sehingga bagi siapa saja yang berkhianat, maka akan dijatuhi sanksi berupa penyiksaan hingga dibunuh, bahkan keluarga mereka pun sangat beresiko untuk dijatuhi hukuman.

${ }^{3}$ Kedua istilah ini dilembagakan melalui surat edaran MA No. 04 Tahun 2011 tentang Perlakuan Bagi Pelapor Tindak Pidana Tertentu (Whistleblower) dan Saksi Pelaku yang Bekerjasama (Justice Collaborators) Didalam Tindak Pidana Tertentu.

4 "Saksi Mahkota" merupakan metode atau strategi yang diaplikasikan oleh aparat penegak hukum dalam mengungkap tabir kejahatan dengan cara salah satu pelaku tindak pidana ditarik sebagai saksi kunci guna mengungkap dan menyeret pelaku-pelaku lainnya dengan kompensasi pengurangan ancaman hukuman. 
dengan berdasarkan konsep Protection of Cooperating Person ${ }^{5}$. Sedangkan bagi negara Anglo Saxon, dalam mengungkap kejahatan cendrung menggunakan konsep Plea Bargaining ${ }^{6}$. Walaupun konsep pendekatan berbeda, namun pada intinya sama dengan konsep Protection of Cooperating Person, yaitu adanya perlindungan hukum terhadap "si tertuduh" berupa kelonggaran hukuman. Olehnya itu, dengan adanya dua konsep pendekatan yang berbeda, negara Eropa Kontinental lebih identik dengan konsep Justice Collaboratorsnya, maka konsep Whistleblowers lebih banyak diusung oleh negara-negara Anglo Saxon, khususnya Amerika dan negara-negara Commonwealth (negara-negara persemakmuran, bekas jajahan Inggris).

Walaupun demikian konsep Whitsleblowers dan Justice Collaborator (konsep Protection of Cooperating Person) merupakan dua hal yang berbeda. Si pengungkap fakta pada konsep Whistleblowers sama sekali tidak dipidana, sedangkan si pengungkap fakta pada konsep Protection of Cooperating Person tetap dapat dipidana namun mendapatkan keringanan. Sebab konsep Protection of Cooperating Person lebih berkonsentrasi kepada pelaku yang bekerjasama dengan penegak hukum (Justice Collaborators) dalam mengungkap kerumitan kasus ${ }^{7}$ yang terbilang rapi, terstruktur dan berjejaring seperti sindikat pengedar narkotika baik berskala nasional maupun internasional.

Peredaran narkotika, suatu kejahatan yang tergolong sebagai kejahatan luar biasa (extra ordinary crime) sangat sulit untuk diberantas . Berada dalam kawasan garis segitiga emas, sindikat The Golden Triangle menjadikan Indonesia sebagai salah satu surga peredaran narkotika di Asia Tenggara. Sindikat The Golden Triangle merupakan sindikat penyelundup narkotika yang meliputi tiga negara penyelundup (Thailand, Laos dan Myammar) dan mulai menggeser posisi

5 Dalam suatu tindak pidana (kejahatan) tertentu, negera dapat memberikan pertimbangan berupa perlindungan hukum bagi tertuduh, berupa pengurangan hukuman apabila tertuduh memberikan kerjasama secara substansial dalam penyelidikan atau penuntutan suatu kejahatan.

${ }^{6}$ Di Amerika Proses negosiasi yang dilakukan oleh penuntut umum bersama dengan terdakwa dengan cara menawarkan kelonggaran hukum terhadap terdakwa guna memperoleh atau mendapatkan pengakuan bersalah

${ }^{7}$ Firman Widjaya, 2011. Whistle Blower dan Justice Collaborator dalam Prespektif Hukum. Penaku, hal.11-12. 
Tiongkok dalam memproduksi dan mengedarkan narkotika dikawasan segi tiga emas Asia Tenggara.

Posisi Indonesia yang berada dalam kawasan segitiga emas (The Golden Triangle) membuat negara seakan tidak berdaya menindak kejahatan ini. Dalam berbagai kasus yang terungkap, aparat penegak hukum (Kepolisian dan Badan Narkotika Nasional) seperti dipencundangi oleh sindikat pengedar narkotika. Tidak tanggung-tanggung, anggota sindikat ini seakan memberikan sinyal kepada aparat penegak hukum agar berhenti menindaki mereka, hukuman penjara tidak efektif dalam menghentikan sepak terjangnya. Berada di balik jeruji besi Lembaga Pemasyarakatan (Lapas) pun, mereka masih sanggup mengendalikan peredaran narkotika di Indonesia.

Badan Narkotika Nasional (BNN) sendiri mengakui, lebih dari $90 \%$ transaksi narkoba yang berhasil diungkap, dikendalikan dalam lapas. ${ }^{8}$ Dan dipenghujung akhir tahun 2019, Deputi Bidang Pemberantasan BNN, Arman Depari menyebut narapidana di 44 Lapas mengendalikan peredaran narkoba di Indonesia. Dirjen Pemasyarakatan (PAS) Kemenkumham Sri Puguh Utami juga tidak memungkiri konsisi ini dan bahkan mengakui sendiri bahwa masih ada oknum lapas yang tidak bersih ${ }^{9}$ yang melakukan kosnspirasi dengan narapidana bandar narkotika dan terbukti pada bulan april 2020, salah seorang pegawai Lapas, terciduk menyelendupkan narkoba kedalam lapas perempuan kelas IIA Denpasar. $^{10}$

Pada kondisi seperti ini, kejahatan sangatlah terstruktur, rapi dan sangat sulit pengungkapannya. Abdul Haris Semendawai ${ }^{11}$ mengemukakan bahwa pada

\footnotetext{
${ }^{8}$ Kompas.com, Kepala BNN: 90 Persen Transaksi Narkoba Dikendalikan dari Dalam Lapas,sumber : https://regional.kompas.com/read/2019/08/14/11164041/kepala-bnn-90-persen -transaksi-narkoba-dikendalikan-dari-dalam-lapas, diakses 25 Mei 2020

9 Detik.com, Ini Penyebab Narkoba di lapas susah dibasmi, sumber: https://news.detik.com/berita-jawa-timur/d-4479356/ini-penyebab-peredaran-narkoba-di-lapassusah-dibasmi, diakses 25 Mei 2020

${ }^{10}$ Tribunnews.com, Pegawai Lapas Perempuan Kelas IIA Denpasar selundupkan Narkoba Terancam Dipecat, Sumber : https://wartakota.tribunnews.com/2020/04/29/pegawai-lapasperempuan-klas-iia-denpasar-selundupkan-narkoba-terancam-dipecat?page=all, diakses $25 \mathrm{Mei}$ 2020

11 Amir Ilyas dan Jupri, 2018. Justice Collaborator; Strategi Menggungkap Tindak Pidana Korupsi. GENTA Publishing, hal. 4
} 
konteks pegungkapan inilah keberadaan seorang Justice Collaborator menjadi hal yang sangat penting dalam membongkar jaringan kejahatan yang selama ini tertutup rapi dan sangat terorganisir. Justice Collaborator merupakan salah satu upaya yang dilakukan untuk membongkar suatu kejahatan yang terorganisir, seperti jaringan mafia.

Sejalan dengan pendapat Indriyanto Seno Adji ${ }^{12}$ yang menyatakan bahwa perkara sulitnya membuka modus operandi kejahatan terorganisir ini, dalam perkembangan penegakan hukum ke depannya juga dilakukan dengan cara luar biasa. Terobosan yang diintrodusir dalam pembuktian kejahatannya, yakni dengan melalui pengungkapan kejahatan yang melibatkan pelaku kejahatan itu sendiri. Inilah yang disebut dengan saksi pelaku yang bekerjasama (Justice Collaborator).

Di Indonesia sendiri, pengungkapan kejahatan dengan menggunakan kerjasama aktif Justice Collaborator telah banyak kali diterapkan ${ }^{13}$.terutama dibidang tindak pidana korupsi. Aparat penegak hukum dalam hal ini Komisi Pemberantasan Korupsi sangat dimudahkan membongkar kejahatan korupsi ${ }^{14}$.. Namun, sangat minim perannya dalam mengungkap tabir kejahatan peredaran narkotika internasional.

Padahal jika ditinjau dari segi regulasi, baik nasional maupun internasional telah tersedia berbagai payung hukum yang memberikan kesempatan bagi setiap orang (pelaku) agar bersedia menjadi Justice Collaborator. Regulasi yang dimaksud tersebar di sejumlah peraturan perundang-undangan, yaitu: (a) UndangUndang Nomor 7 Tahun 2006 Tentang Pengesahan United Nations Convention Againts Corruption, 2003 (Konvensi Perserikatan Bangsa-Bangsa Anti Korupsi, 2003); (b) Undang-Undang Nomor 5 Tahun 2009 Tentang Pengesahan Convention Against Transnational Organized Crimes/UNCATOC (Konvensi PBB Anti Kejahatan Transnasional yang Terorganisir); (c) Undang-Undang Nomor 13

\footnotetext{
12 Jupri, Reward Keringan Sanksi Pidana bagi Justice Collaborator Perkara Korupsi. Jurnal Transformative, Volume 4 Nomor 1, Maret 2018, hal. 19.

${ }^{13}$ Lihat dalam Amir Ilyas dan Jupri, 2018. Justice Collaborator; Strategi Menggungkap Tindak Pidana Korupsi. GENTA Publishing, hlm. 48.

${ }^{14}$ Contoh kasus besar yang dibongkar KPK dengan menggunakan peran Justice Collaborator; Suap cek pelawat pemilihan Deputi Gubernur Senior Bank Indonesia, suap dalam pembangunan Wisma Atlet, pembangunan sport center Hambalang dan Simulator SIM
} 
Tahun 2006 Juncto Undang-Undang Nomor 31 Tahun 2014 Tentang Perlindungan Saksi dan Korban; (d) Peraturan Pemerintah Nomor 99 Tahun 2012 tentang Syarat dan Tata Cara Pelaksanaan Hak Warga Binaan Pemasyarakatan; (e) Peraturan Bersama Nomor: m.hh-11.hm.03.02.th.2011, Nomor: per045/a/ja/12/2011, Nomor: 1 tahun 2011, Nomor kepb-02/01-55/12/2011, Nomor: 4 tahun 2011 tentang Perlindungan Bagi Pelapor, Saksi Pelapor dan Saksi Pelaku yang Bekerjasama; dan yang terbarun (f) Surat Edaran Mahkamah Agung (SEMA) Nomor 4 Tahun 2011 Tentang Perlakuan Bagi Pelapor Tindak Pidana (Whistleblower) dan Saksi Pelaku Yang Bekerjasama (Justice Collaborator) Di Dalam Perkara Tindak Pidana Tertentu.

Berdasarkan uraian sebelumnya dan melihat sejumlah regulasi di atas, maka sehubungan dengan penelitian ini dapat ditarik 2 (dua) hal penting yang Pertama, Justice Collaborator diterapkan untuk kejahatan yang terorganisir seperti sindikat peredaran narkotika. Kedua, seseorang yang berstatus Justice Collaborator menjadi persyaratan penting dalam pemberian remisi terhadap narapidana hal ini apabila merujuk Pasal 14 Ayat (1) huruf (i) UU No. 12 Tahun 1995 tentang Pemasyarakatan, yang mengatur remisi atau pengurangan masa pidana merupakan hak dari warga binaan (narapidana) tanpa harus melihat perbedaan dari segi tipologi kejahatan yang dilakukan. Namun. pro kontra pun lahir kemudian, ketika pemerintah menerbitkan Peraturan Pemerintah (PP) No. 99 Tahun 2012 dan mengandung materi muatan yang dianggap diskriminatif dan bertentangan dengan UU Nomor 12 Tahun 1995 tentang Pemasyarakatan, khususnya hak remisi bagi narapidana. Olehnya itu melalui penelitian ini, penulis akan mengkaji bagaimana pemberian hak remis bagi narapidana narkotika berstatus justice collaborator di Lapas Klas III Pohuwato khususnya.

\section{B. Metode Penelitian}

Penelitian ini merupakan penelitian hukum normatif-empiris, yaitu penelitian hukum yang kajiannya meliputi ketentuan perundang-undangan (in abstracto) dihubungkan dengan penerapannya di lapangan (in concreto). Lokasi penelitian dilakukan di Lapas Klas III Pohuwato, Provinsi Gorontalo, Indonesia . 
Tipe penelitiannya adalah deskriptis, yaitu memaparkan secara jelas dan sistematis. Adapun jenis dan sumber data yang digunakan dalam mengkaji dan menelah penelitian, yaitu terdiri dari (1) data primer, yaitu data yang diperoleh dari sumber pertama yaitu responden serta observasi secara langsung dilapangan;(2) data skunder, yaitu data yang diperoleh dilapangan berupa karya ilmiah, buku atau laporan-laporan. Data dalam penelitian ini diperoleh melalui kegiatan observasi dan interview (wawancara langsung). Disamping itu penelitian ini juga dilengkapai dengan library research tentang teori-teori yang mendukung analisis persoalan yang diajukan maupun hukum posistif berupa peraturan perundang-undangan yang terkait dengan Justice Collaborator dan hak warga binaan dalam pemasyarakatan.

\section{Pembahasan}

\section{Tindak Pidana Narkotika Sebagai Kejahatan Terorganisir (Organized} Crime)

Kejahatan Narkotika dikategorikan sebagai kejahatan yang luar biasa (extra ordinary crime) dengan demikian perlu penanganan yang luar biasa dalam pemberantasan tindak pidana narkotika. Dalam rangka pemberantasan Tindak Pidana Narkotika di Indonesia, dibentuklah Undang-Undang Nomor 35 tahun 2009 Tentang Narkotika. UndangUndang No. 35 Tahun 2009 ini lahir sebagai bagian dari respon negara terhadap kecendrungan tindak pidana narkotika yang terus meningkat baik secara kualitatif maupun kuantitatif dengan korban yang meluas, terutama di kalangan anak-anak, remaja, dan generasi muda pada umumnya.

Dalam penjelasan Undang-Undang Nomor 35 Tahun 2009 dinyatakan bahwa: "Tindak Pidana Narkotika tidak lagi dilakukan secara perseorangan, melainkan melibatkan banyak pihak yang secara bersama sama, bahkan merupakan satu sindikat yang terorganisasi dengan jaringan yang luas, bekerja secara rapi dan sangat rahasia baik di tingkat regional, 
nasional maupun internasional. Selain itu, untuk melindungi masyarakat dari bahaya penyalahgunaan narkotika, dan mencegah serta memberantas peredaran gelap narkotika, dalam undang-undang ini diatur pula mengenai prekursor narkotika ( merupakan zat atau bahan pemula atau bahan kimia yang dapat digunakan dalam pembuatan Narkotika).

Pada kalimat "satu sindikat yang terorganisasi dengan jaringan yang luas yang bekerja secara rapi dan sangat rahasia baik di tingkat nasional maupun internasional" jelaslah terlihat bahwa penyalahgunaan narkotika tegas dikategorikan sebagai kejahatan terorganisir dan lintas negara. Jenis-jenis kejahatan tersebut dapat diklasifikasikan berdasarkan tipologinya yakni dikenal istilah kejahatan konvensional (blue collar crime), kejahatan biasa (ordinary crime), dan kejahatan luar biasa (extra ordinary crime), national crime, international crime, dan transnational crime.

Perbedaan tipe kejahatan, dapat dilihat dari uraian Light, Keller dan Calhoun yang membedakan tipe kejahatan menjadi empat ${ }^{15}$, yaitu: Pertama; kejahatan tanpa korban (crime without victim). Jenis kejahatan ini tidak menimbulkan penderiataan terhadapp korban akibat tindak pidana yang dilakukan oleh orang lain. Sebagai contoh perbuatan perjudian, penyalahgunaan obat bius (narkotika), mabuk-mabukan, hubungan seks yang tidak sah yang dilakukan secara sukarela orang dewasa. Meskipun tidak membawa korban, perilaku-perilaku ini tetap digolongkan sebagai perilaku menyimpang oleh masyarakat. Kejahatan seperti ini dapat mengorbankan orang lain apabila menyebabkan tindakan negatif lebih lanjut. Misalnya, seseorang yang terkena HIV/AIDS, pencurian, dll; Kedua, Kejahatan Terorganisasi (organized crime) ${ }^{16}$. Pelaku kejahatan

${ }^{15}$ Lilik Mulyadi, 2015. Perlindungan Hukum Whistleblower \& Justice Collaborator; Dalam upaya Penanggulangan Organized Crime. Alumni, hal...32-33.

${ }^{16}$ Kejahatan terorganisir adalah istilah yang sangat ringkas dan tajam yang telah menjadi bagian dari kosa kata banyak politisi dan masyarakat luas. Istilah ini sering diterapkan tanpa poin referensi yang jelas, dan pada kenyataannya sangat tidak menentukan dan sama-samar, Pirre 
merupakan sindikat yang berkesinambungan melakukan segala cara dan upaya cara untuk memperoleh uang maupun kekuasaan dengan jalan menghindari hukum. Misalnya, sindikat prostitusi dan perdagangan orang, sindikat penadah barang curian, perjudian gelap, sindikat korupsi dll. Jika kejahatan tersebut melibatkan hubungan antarnegara disebut kejahatan terorganisasi transnasional. Contoh sindikat pengedar narkotika internasional, sindikat perdagangan bayi dan anak lintas batas negara, sindikat prostitusi internasional dengan menjual perempuan ke Jepang atau Thailand untuk dijadikan budak seks atau dieksploitasi secara seksual,; Ketiga, kejahatan kerah putih (white collar crime). Kejahatan ini merupakan tipe kejahatan yang mengacu pada kejahatan yang dilakukan oleh orang yang memiliki status sosial tinggi dalam pekerjaan dan masyarakat atau lebih ringkasnya adalah kejahatan yang dilakukan oleh orang terpandang. Contoh, fraud dalam dunia perbankan, penggelapan uang perusahaan oleh pemilik perusahaan, penghindaran pajak, atau pejabat negara yang melakukan korupsi; dan keempat, kejahatan korporasi (corporate crime). Kejahatan ini merupakan jenis kejahatan yang dilakukan atas nama organisasi dengan tujuan menaikkan keuntungan atau menekan kerugian. Misalnya, suatu perusahaan membuang limbah racun ke sungai dan mengakibatkan penduduk sekitar mengalami berbagai jenis penyakit.

Berdasarkan tipologi kejahatan, maka dapat ditarik kesimpulan tindak pidana narkotika masuk dalam beberapa tipologi kejahatan. Pertama, tergolong kejahatan tanpa korban. Khusus untuk pengguna, karena mengkonsumsi narkoba untuk diri sendiri. Kedua, kejahatan terorganisir (organized crime). Sudah menjadi rahasia umum, peredaran narkotika di Indonesia sangat terorganisir. Mulai dari produsen, pengedar sampai ke pemakainya. Ketiga, narkotika tergolong transnational crime.

Hauck dan Sven Peterke, Kejahatan Terorganisir dan Kekerasan Geng dalam Hukum Nasional dan Internasional, dalam; International Review of The Red Cross, Volume 92, Number 878, Edisi June 2010, hal.45. Lihat juga dalam Lilik Mulyadi, Ibid, hal. 34-35. 
Mengapa transnational crime, karena dalam hal melakukan kejahatannya meliputi lintas negara.

Bila kita kembali kepada peran aktif Justice Collaborator dalam menggungkap kejahatan teroranisir seperti jaringan Narkotika. Maka tentunya, pemerintah memiliki kewajiban memberikan perlindungan dan penghargaan (reward) bagi saksi pelaku yang bekerjasama. Khusus pada pemberian hak remisi bagi terpidana penyalahgunaan narkotika di Lembaga Pemasasyarakatan.

\section{Pemberian Hak Remisi Terhadap Narapidana Narkotika Berstatus Justice Collaborator.}

Kejahatan narkotika sebagai organized crime dan transnational crime, haruslah selalu mendapatkan perhatian. Termasuk terhadap pelaku yang telah berstatus sebagai narapidana. Hal ini penting sebab, saat ini Lapas seolah telah bertransformasi menjadi pusat kendali peredaran narkoba yang terus menggurita. Hal ini menjadi tantangan tersendiri bagi aparat penegak. Sebab berdasarkan regulasi, narapidana narkotika memiliki hak yang sama dengan narapidana tindak pidana umum lainnya. Namun, dari realitas yang terjadi dapat diasumsikan bahwa narapidana narkotika (bandar narkoba) lebih aman berada dikungkungan jeruji besi dalam mengendalikan peredaran narkoba di Indonesia sehingga abai terhadap hak untuk mendapatkan pengurangan masa hukuman (remisi) melalui metode Justice Collaborator.

Jika merujuk Pasal 14 ayat (1) Undang-Undang Nomor 12 Tahun 1995 tentang Pemasyarakatan, maka hak-hak terpidana sebagai berikut: (i) Narapidana berhak melakukan ibadah sesuai dengan agama dan kepercayaannya yang berarti dalam hal ini dijelaskan bahwa narapidana di dalam lapas tidak boleh dihalangi beribadah menurut agama dan kepercayaannya; (ii) Mendapat perawatan, baik perawatan rohani maupun jasmani. Perawatan rohani berarti terpidana berhak untuk mengikuti acara 
keagamaan yang diadakan di dalam lapas sesuai agamanya masing-masing dan perawatan jasmani berhak untuk merawat dirinya di dalam lapas. (iii) Mendapatkan pendidikan dan pengajaran. Pendidikan dalam hal ini adalah mendapatkan ilmu dalam berbagai kegiatan di dalam lembaga pemasyarakatan dan pengajaran berupa keterampilan di dalam lapas; (iv) Mendapatkan pelayanan kesehatan dan makanan yang layak. Narapidana berhak mendapatkan pelayanan kesehatan jika narapidana menderita penyakit serta berhak pula mendapatkan makanan yang layak pada setiap kali narapidana menerima makanan di Lapas. (v) Menyampaikan keluhan berarti jika ada sesuatu hak yang tidak mereka terima di Lapas mereka berhak melaporkan ke Petugas Lapas; (vi) Mendapatkan bahan bacaan dan mengikuti siaran media massa lainnya yang tidak dilarang yang berarti mendapat bahan bacaan seperti koran dan majalah serta dapat menonton televisi pada saluran resmi yang telah diijinkan oleh KPI; (vii) Mendapatkan upah atau premi atas pekerjaan yang dilakukan artinya dapat menerima upah atas pekerjaan yang mereka lakukan di Lapas; (viii) Menerima kunjungan keluarga, penasihat hukum, atau orang tertentu lainnya, artinya dapat bertemu dengan keluarga, penasihat hukum ataupun orang tertentu lainnya jika mereka berkunjung ke Lapas; (ix) Mendapatkan pengurangan masa pidana (remisi) artinya dapat mendapatkan pengurangan masa tahanan pada hari kemerdekaan dan hari raya keagamaan sesuai agamanya masing-masing; (x) Mendapatkan kesempatan berasimilasi termasuk cuti mengunjungi keluarga artinya dapat mengikuti kegiatan di luar lapas termasuk bekerja di luar lapas dan juga dapat keluar tahanan untuk mengunjungi keluarga; (xi)Mendapatkan pembebasan bersyarat artinya jika sudah menjalani masa tahanan 2/3 dari masa hukuman pidana dapat mengajukan bebas bersyarat dan mendapatkan pembebasan bersyarat tersebut. (xii) Mendapatkan cuti menjelang bebas. (xiii) Mendapatkan hak-hak lain sesuai dengan peraturan perundang-undangan yang berlaku. 
Dalam hal pemberian hak remisi, bila merujuk Pasal 14 Ayat (1) UU No. 12 Tahun 1995 di atas pada poin (ix), narapidana berhak mendapatkan pengurangan masa pidana (remisi). Namun, pemberian remisi terhadap narapidana tindak pidana narkotika harus di batasi pemberiannya karena kejahatan tersebut merupakan kejahatan yang sangat serius mengancam generasi penerus bangsa.

Lahirnya Peraturan Pemerintah Republik Indonesia Nomor 99 Tahun 2012 Tentang Perubahan Kedua Atas Peraturan Pemerintah Nomor 32 Tahun 1999 Tentang Syarat dan Tata Cara Pelaksanaan Hak Warga Binaan Pemasyarakatan, yang mengatur mengenai pengaturan remisi tersebut terdapat di dalam Pasal 34 Ayat 1, Ayat 2 dan Ayat 3 yang mengatur bahwah setiap narapidana dan anak pidana berhak mendapatkan remisi dengan ketentuan telah memenuhi 2 (dua) syarat, yaitu berkelakuan baik dan telah menjalani masa pidana lebih dari 6 (enam) bulan. Adapun mengenai persyaratan berkelakuan baik harus dibuktikan dengan: (a) tidak sedang menjalani hukuman disiplin dalam kurun waktu 6 (enam) bulan terakhir, terhitung sebelum tanggal pemberian Remisi; dan (b). telah mengikuti program pembinaan yang diselenggarakan oleh lembaga pemasyarakatan dengan predikat baik.

Selanjutnya remisi terpidana narkotika telah diatur lebih jauh dalam ketentuan Pasal 34A Ayat 1 Huruf (a) yang mengatur ketetuan bahwa pemberian remisi bagi narapidana yang dipidana narkotika dan prekursor narkotika, psikotropika selain harus memenuhi persyaratan sebagaimana di maksud dalam Pasal 34 juga harus memenuhi persyaratan "bersedia berkerjasama dengan penegak hukum untuk membantu membongkar perkara tindak pidana yang di lakukannya”. Ketentuan ini hanya berlaku bagi narapidana dengan pidana penjara paling singkat 5 tahun (Pasal 34 A huruf b).

Dengan adanya ketentuan sebagaimana yang disebutkan diatas dan menjadi materi muatan yang diatur dalam PP Nomor 99 Tahun 2012 oleh 
sebahagian orang termasuk menteri Hukum dan HAM, Yasonna Laoly dianggap diskriminatif dan bertentangan dengan UU Nomor 12 Tahun 1995 tentang Pemasyarakatan, terkhusus hak remisi bagi narapidana. Lalu pertanyaannya bagaimana dengan pemberian hak remisi narapidana di Lapas Kelas III Pohuwoto. Berdasarkan penelitian di Lapas Klas III Pohuwato, khusus jumlah warga binaan dari segi tipologi kejahatan dapat di lihat pada tabel 1 .

Tabel 1

Warga Binaan di Lapas Klas III Pohuwato

\begin{tabular}{|c|c|c|}
\hline Jenis kejahatan & Narapidana & Tahanan \\
\hline Mata uang & - & - \\
\hline Perjudian & 4 orang & - \\
\hline Pembunuhan & 17 orang & 1 orang \\
\hline Pencurian & 14 orang & 1 orang \\
\hline Perampokan & - & - \\
\hline Penipuan & 2 orang & - \\
\hline Narkotika & 28 orang & 9 orang \\
\hline Korupsi & 11 orang & - \\
\hline Kepabeanan & - & - \\
\hline Psikotropika & - & - \\
\hline Teroris & - & - \\
\hline Perlindungan anak & 39 orang & 4 orang \\
\hline Kehutanan & - & - \\
\hline Hak cipta & - & - \\
\hline KDRT & 2 orang & - \\
\hline Senjata tajam & 1 orang & - \\
\hline Lain-lain & 15 orang & 2 orang \\
\hline Total & 133 orng & 17 orng \\
\hline
\end{tabular}

Sumber : Sub Bagian Registrasi Lapas Klas III Pohuwato, diolah 2019 
Pada tabel 1 di atas, terlihat dari total 133 orang narapidana di Lapas Kelas III Pohuwato, terdapat narapidana khusus narkotika sebanyak 28 narapidana dan 9 orang tahanan yang dititipkan di Lapas. Sisanya, narapidana kasus pembunuhan 17 orang, perjudian 4 orang, pencurian 12 orang, penipuan 2 orang, perlindungan anak ada 39 orang, KDRT 2 orang, senjata tajam, 1 orang, dan lain-lain 15 orang.

Adapun daftar identitas narapidana narkotika pada Lapas Klas III Pohuwato dapat dilihat pada tabel 2.

Tabel 2.

Daftar Nama Narapidana Narkotika Lapas Klas III Pohuwato per Januari 2019

\begin{tabular}{|c|c|c|c|c|}
\hline No & Nama & Usia & Pekerjaan & Pidana \\
\hline \multirow[t]{2}{*}{1} & Sumarno Bin & 37 & Sopir & 9 Tahun 4 Bulan \\
\hline & Muslimin & & & \\
\hline \multirow[t]{2}{*}{2} & Abdullah Bin H. & 62 & Sopir & 9 Tahun 4 Bulan \\
\hline & Naong (alm) & & & \\
\hline \multirow[t]{2}{*}{3} & Andi Aso Bin Andi & 40 & Wiraswasta & 9 Tahun 4 Bulan \\
\hline & Padudu & & & \\
\hline \multirow[t]{2}{*}{4} & Taufik Sawali Bin & 28 & Pelajar/Mahasiswa & 6 Tahun \\
\hline & Rusno Sawali & & & \\
\hline \multirow[t]{2}{*}{5} & A. Chaerul Bin Andi & 30 & Wiraswasta & 8 Tahun \\
\hline & Kasri & & & \\
\hline \multirow[t]{2}{*}{6} & Sempo Bin La Tanga & 40 & Sopir & 4 Tahun \\
\hline & $(\mathrm{ALM})$ & & & \\
\hline \multirow[t]{3}{*}{7} & Suripto Mokodompit & 40 & & 6 Tahun \\
\hline & Bin Sahidun & & & \\
\hline & Mokodompit & & & \\
\hline \multirow[t]{2}{*}{8} & Syaidiman Bin & 28 & Wiraswasta & 6 Tahun \\
\hline & Hasanudin Usman & & & \\
\hline 9 & Andi Polumulo Bin B & 28 & Sopir & 7 Tahun \\
\hline 10 & Anwar Oka Bin & 30 & Karyawan Swasta & 7 Tahun 6 Bulan \\
\hline
\end{tabular}




\begin{tabular}{|c|c|c|c|c|}
\hline No & Nama & Usia & Pekerjaan & Pidana \\
\hline & Lukman Oka & & & \\
\hline 11 & Sair Bin Bunnaing & 25 & Sopir & 7 Tahun \\
\hline \multirow[t]{2}{*}{12} & Faizal Bin $\mathrm{Hj}$. & 34 & Karyawan Swasta & 7 Tahun \\
\hline & Samsudin M.Tang & & & \\
\hline 13 & Hermanto Bin Gising & 40 & Petani/Pekebun & 7 Tahun \\
\hline \multirow[t]{2}{*}{14} & Budianto Pakaya Bin & 40 & Karyawan Swasta & 7 Tahun \\
\hline & Hermah & & & \\
\hline \multirow[t]{2}{*}{15} & Ibrahim Assagaf Bin & 26 & Wiraswasta & 4 Tahun \\
\hline & Alm.Madrik Assagaf & & & \\
\hline \multirow[t]{2}{*}{16} & Hardiansyah A.Tolaba & 29 & Pedagang & 13 Tahun 8 \\
\hline & Bin Asdar Tolaba & & & Bulan \\
\hline \multirow[t]{2}{*}{17} & Hasim Lapungge Bin & 45 & Karyawan Swasta & 8 Tahun \\
\hline & Monoistooma & & & \\
\hline \multirow[t]{2}{*}{18} & Rifaldy Manopo Bin & 24 & Pelajar/Mahasiswa & 4 Tahun \\
\hline & Jimi manopo & & & \\
\hline \multirow[t]{2}{*}{19} & Ariyanto Bobihu Bin & 24 & Tidak Bekerja & 4 Tahun \\
\hline & Parno Bobihu & & & \\
\hline \multirow[t]{2}{*}{20} & Siswanto Uno Bin & 22 & Lain-Lain & 2 Tahun \\
\hline & Noldi Uno & & & \\
\hline \multirow[t]{2}{*}{21} & Alex Karama Bin & 46 & Wiraswasta & 4 Tahun \\
\hline & Reing Karama & & & \\
\hline \multirow[t]{2}{*}{22} & Efrito Dunggio Bin & 22 & Tidak Bekerja & 5 Tahun \\
\hline & Eman Dunggio & & & \\
\hline \multirow[t]{2}{*}{23} & Iwan lahay bin alm. & 48 & Buruh & 5 Tahun \\
\hline & Nino lahay & & Tani/Perkebunan & \\
\hline \multirow[t]{2}{*}{24} & Meykel Pakaya Bin & 39 & Karyawan Swasta & 1 Tahun 2 Bulan \\
\hline & Raden Pakaya & & & \\
\hline \multirow[t]{2}{*}{25} & Aji Saputra Bin Sinen & 32 & Sopir & 1 Tahun 6 Bulan \\
\hline & Magori & & & \\
\hline
\end{tabular}




\begin{tabular}{llccc}
\hline No & \multicolumn{1}{c}{ Nama } & Usia & Pekerjaan & Pidana \\
\hline 26 & Fandi Mantiri Bin & 28 & Wiraswasta & 5 Tahun \\
& Hendra Mantiri & & & \\
27 & Taufik Masulili Bin & 30 & Petani/Pekebun & 5 Tahun \\
& Nazamudin Masulili & & & \\
28 & Moh. Alvin Salama & 22 & Pedagang & 1 Tahun 4 Bulan \\
& Bin Mohamad & & & \\
& Indayah Salama & & & \\
\hline
\end{tabular}

Sumber : Sub Bagian Registrasi Lapas Klas III Pohuwato, diolah 2019

Berdasarkan tabel 2 di atas dapat diketahui bahwa total narapidana narkotika pada Lapas Klas III Pohuwato berjumlah 28 orang dengan umur narapidana termuda 22 tahun dan tertua 62 tahun. Para narapidana memiliki beragam pekerjaan yakni Sopir, Wiraswasta, Pelajar/Mahasiswa, Karyawan Swasta, Petani/Pekebun, Pedagang, dan Buruh Tani/Perkebunan. Selain itu hukuman narapidana yang paling singkat adalah 1 tahun 2 bulan dan paling lama 13 tahun 8 bulan.

Kembali ke wilayah pemberian hak remisi bagi narapidana, bila berpegang pada Undang-Undang Nomor 12 Tahun 1995 tentang Pemasyarakatan. Menurut peneliti pemberian remisi yang ditetapkan di dalam Pasal 14 merupakan hak yang dapat dibatasi keberadaannya. Remisi tidak bisa dihilangkan tetapi bisa dibatasi sebagaimana diatur dalam PP No. 99 tahun 2012 yang mengatur pemberian remisi terhadap narapidana tindak pidana luar biasa terkhusus narkotika lebih diketatkan yakni dengan memberikan syarat tambahan. Syarat pokoknya adalah berkelakuan baik dan menjalani masa pidana lebih dari 6 bulan. Sedangkan syarat tambahannya narapidana harus menjadi Justice Collaborator yang dinyatakan secara tertulis dan ditetapkan instansi penegak hukum sesuai peraturan perundang-undangan.

Sesuatu hal yang urgent bagi narapidan agar bersedia menjadi Justice Collaborator, khususnya di Provinsi Gorontalo mengingat bahwa berdasarkan rilis dari BNN tentang kawasan rawan narkoba di Indonesia tahun 2019, terdapat 
tiga kawasan yang rawan peredaran narkoba, yaitu (i) Kelurahan Biawu. Kec. Kota Selatan, Kota Gorontalo, (ii) Kel. Biawao, Kec. Kota Selatan, Gorontalo, dan (iii) Desa Tolotio, Kec. Tibawa, Kab. Gorontalo ${ }^{17}$. Selain terdapat tiga kawasan rawan narkoba, angka pengguna narkoba di provinsi ini juga terbilang tinggi yaitu terdapat 10.244 orang di tahun 2019, bahkan di tahun 2019 dari 110 kasus yang ditangai BNN Gorontalo, pelakunya di dominasi oleh pelajar.

Namun, terlepas dari angka-angka yang mengkhawtirkan diatas, berdasarkan hasil wawancara Peneliti dengan Sub Admisi dan Orientasi Lapas Klas III Pohuwato, $\mathrm{Ikbal}^{18}$ menegaskan bahwa hak untuk mendapatkan remisi merupakan hak yang wajib dipenuhi oleh Lembaga Pemasyarakatan. Pemberian hak remisi tersebut harus berdasarkan aturan yang telah dibuat oleh pemerintah yang diatur di dalam PP No. 99 Tahun 2012 tentang Syarat dan Tata Cara Pelaksanaan Hak Warga Binaan Pemasyarakatan dan Kepres No. 174 Tahun 1999 tentang Remisi. Sedangkan, khusus narapidana yang memperoleh remisi berdasarkan UU Nomor 12 Tahun 1995 tentang Pemasyarakatan dan sesuai PP No. 99 Tahun 2012 khusus yang memenuhi status sebagai Justice Collaborator adalah sebagai berikut: Lihat tabel 3.

Tabel 3.

Data Narapidana Narkotika yang mendapatkan Remisi

\begin{tabular}{|c|c|c|c|c|c|c|}
\hline No & Nama & Umur & Pekerjaan & Hukuman & $\begin{array}{l}\text { Total } \\
\text { bulan } \\
\text { remisi }\end{array}$ & $\begin{array}{r}\text { Total } \\
\text { hari } \\
\text { remisi }\end{array}$ \\
\hline 1 & $\begin{array}{l}\text { A. Chaerul } \\
\text { Bin Andi } \\
\text { Kasri }\end{array}$ & 30 & Wiraswasta & 8 Tahun & 3 & 0 \\
\hline 2 & $\begin{array}{l}\text { Sempo Bin } \\
\text { La Tanga } \\
(\text { Alm) }\end{array}$ & 40 & Sopir & 4 Tahun & 1 & 15 \\
\hline
\end{tabular}

17 BNN.go.id, Daftar Kawasan Rawan Narkoba di Indonesia Tahun 2019, sumber: https://bnn.go.id/daftar-kawasan-rawan-narkoba-indonesia-tahun-2019/

${ }^{18}$ Wawancara pada tanggal 25 Februari 2019. 


\begin{tabular}{|c|c|c|c|c|c|c|}
\hline No & Nama & Umur & Pekerjaan & Hukuman & $\begin{array}{l}\text { Total } \\
\text { bulan } \\
\text { remisi }\end{array}$ & $\begin{array}{c}\text { Total } \\
\text { hari } \\
\text { remisi }\end{array}$ \\
\hline 更 & $\begin{array}{l}\text { Suripto } \\
\text { Mokodomp } \\
\text { it Bin } \\
\text { Sahidun } \\
\text { Mokodomp } \\
\text { it }\end{array}$ & 40 & - & 6 Tahun & 12 & 0 \\
\hline 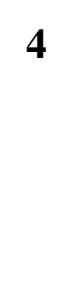 & $\begin{array}{l}\text { Anwar Oka } \\
\text { Bin } \\
\text { Lukman } \\
\text { Oka }\end{array}$ & 30 & $\begin{array}{c}\text { Karyawan } \\
\text { Swasta }\end{array}$ & $\begin{array}{c}7 \text { Tahun } 6 \\
\text { Bulan }\end{array}$ & 5 & 15 \\
\hline 更 & $\begin{array}{l}\text { Faizal Bin } \\
\mathrm{Hj} . \\
\text { Samsudin } \\
\text { M.Tang }\end{array}$ & 34 & $\begin{array}{c}\text { Karyawan } \\
\text { Swasta }\end{array}$ & 7 Tahun & 3 & 0 \\
\hline 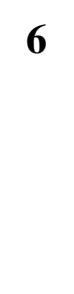 & $\begin{array}{l}\text { Ibrahim } \\
\text { Assagaf Bin } \\
\text { Alm.Madri } \\
\text { k Assagaf }\end{array}$ & 26 & Wiraswasta & 4 Tahun & 3 & 0 \\
\hline 更 & $\begin{array}{l}\text { Rifaldy } \\
\text { Manopo } \\
\text { Bin Jimi } \\
\text { manopo }\end{array}$ & 24 & $\begin{array}{c}\text { Pelajar/Ma } \\
\text { hasiswa }\end{array}$ & 4 Tahun & 2 & 15 \\
\hline 8 & $\begin{array}{l}\text { Ariyanto } \\
\text { Bobihu Bin } \\
\text { Parno } \\
\text { Bobihu }\end{array}$ & 24 & $\begin{array}{l}\text { Tidak } \\
\text { Bekerja }\end{array}$ & 4 Tahun & 1 & 15 \\
\hline
\end{tabular}

Sumber : Sub Bagian Registrasi Lapas Klas III Pohuwato, diolah 2019 
Berdasarkan data tabel 3 di atas, dari 28 orang narapidana narkotika hanya 8 orang yang mendapatkan remisi dengan jumlah hari yang berbeda-beda. Hal ini dikarenakan persyaratan yang ada pada PP No. 99 Tahun 2012 yang semakin ketat. Sebagaimana dikuatkan oleh anggota di Sub Admisi dan Orientasi Lapas Klas III Pohuwato, $\mathrm{Ikbal}^{19}$ menyatakan bahwa sebanyak 8 orang yang mendapatkan remisi, ada 4 yang hukuman penjaranya di atas 5 tahun penjara dan 4 lagi di bawah hukuman penjara 5 tahun. Sedangkan 20 orang terpidana lainnya tidak atau belum mendapatkan remisi dan terkendala di surat JC (Justice Collaborator) dari penyidik/ kejaksaan serta tidak termasuk di register F.

\section{E. Penutup}

Berdasarkan jumlah narapidana narkotika di Lapas Klas III Pohuwato, Provinsi Gorontalo, Indonesia yang mencapai 28 orang narapidana narkotika, hanya 8 orang yang mendapatkan remisi karena berstatus Justice Collaborators. Sedangkan untuk 20 orang narapidana yang lain, tidak atau belum mendapatkan remisi, hal ini disebabkan oleh tidak adanya surat dari penyidik/kejaksaan terkait statusnya sebagai Justice Collaborator. Bila berpegang pada UU Nomor 12 Tahun 1995 tentang Pemasyarakatan, maka hak untuk mendapatkan remisi merupakan hak yang wajib dipenuhi oleh Lembaga Pemasyarakatan. Namun menurut kajian peneliti pemberian remisi yang ditetapkan di dalam Pasal 14 UU No. 12 Tahun 1995 merupakan hak yang dapat dibatasi keberadaannya terutama kejahatan yang bersifat terorganisir seperti Narkotika. Remisi tidak bisa dihilangkan tetapi bisa dibatasi. Peraturan Pemerintah Nomor 99 tahun 2012 menetapkan bahwa syarat dalam pemberian remisi terhadap narapidana tindak pidana luar biasa terkhusus narkotika lebih diketatkan, yakni dengan memberikan syarat tambahan. Syarat pokoknya adalah berkelakuan baik dan menjalani masa pidana lebih dari 6 bulan. Sedangkan syarat tambahannya narapidana harus menjadi Justice Collaborator yang dinyatakan secara tertulis dan ditetapkan instansi penegak hukum sesuai peraturan perundang-undangan, membayar lunas denda dan uang pengganti sesuai dengan putusan pengadilan.

\footnotetext{
${ }^{19}$ Wawancara tanggal 25 Februari 2019.
} 


\section{Daftar Pustaka}

\section{Buku dan Artikel IImiah}

Amir Ilyas dan Jupri, 2018. Justice Collaborator Strategi Mengungkap Tindak Pidana Korupsi. GENTA Publishing. Jogjakarta

Firman Widjaya, 2011. Whistle Blower dan Justice Collaborator dalam Prespektif Hukum. Penaku. Jakarta

Jupri, Reward Keringanan Sanksi Pidana Bagi Justice Collaborator Perkara Korupsi. Jurnal Transformative Universitas Brawijaya. Volume 4. No. 1, Edisi Maret 2018.

Lilik Mulyadi, 2015. Perlindungan Whistleblower \& Justice Collaborator dalam upaya Penanggulangan Organized Crime. Alumni. Bandung

Pirre Hauck dan Sven Peterke, International Review of The Red Cross, Volume 92, Number 878, Edisi June 2010.

\section{Website}

BNN.go.id, Daftar Kawasan Rawan Narkoba di Indonesia Tahun 2019, sumber: https://bnn.go.id/daftar-kawasan-rawan-narkoba-indonesia-tahun-2019/, diakses 25 Mei 2020.

Detik.com, Ini Penyebab Narkoba di lapas susah dibasmi, sumber: https://news.detik.com/berita-jawa-timur/d-4479356/ini-penyebab-peredaran-narkoba-di-lapas-susah-dibasmi, diakses 25 Mei 2020.

Kompas.com, Kepala BNN: 90 Persen Transaksi Narkoba Dikendalikan dari Dalam Lapas, sumber :https://regional.kompas.com/read/2019/08/14/ 11164041/kepala-bnn- 90-persen-transaksi-narkoba-dikendalikan-daridalam-lapas, diakses 25 Mei 2020.

Tribunnews.com, Pegawai Lapas Perempuan Kelas IIA Denpasar selundupkan Narkoba Terancam Dipecat, Sumber : https://wartakota. tribunnews. com/2020/04/29/pegawai-lapas-perempuan-klas-iia-denpasar-selundupkan-narkoba-terancam-dipecat?page=all, diakses 25 Mei 2020.

\section{Peraturan Perundang-Undangan}

Undang-Undang Republik Indonesia Nomor 12 Tahun 1995 Tentang Pemasyarakatan.

Peraturan Pemerintah Republik Indonesia Nomor 99 Tahun 2012 Tentang Perubahan Kedua Atas Peraturan Pemerintah Nomor 32 Tahun 1999 Tentang Syarat dan Tata Cara Pelaksanaan Hak Warga Binaan Pemasyarakatan. 